\title{
A review of field methods to survey coastal dunes-experience based on research from South Baltic coast
}

\author{
Tomasz A. Labuz ${ }^{1}$
}

Received: 25 June 2015 /Revised: 10 February 2016 / Accepted: 11 February 2016 /Published online: 2 March 2016

(C) The Author(s) 2016. This article is published with open access at Springerlink.com

\begin{abstract}
The aim of this paper is to compare the usefulness of equipment employed for foredune ground surveys in different environmental conditions based on literature and field experience from the Polish coast. This article contains a description of recently used methods of coastal dunes monitoring for management and scientific purposes. It presents issues of coastal dunes mapping that are a part of long-term research conducted along the Polish coast since 1997. The employed methods and techniques are briefly described and evaluated. Subsequently, a description and assessment of these field surveys is provided. The description of techniques is focused on the aim of the research and on the types of morphological coastal forms and vegetation cover. Those full descriptions may allow the choice of a proper method for field investigation suited to the researcher's need. The precision of measurement techniques and collected data is presented. Those data fulfill the need for geomorphologic investigation in coastal dune areas. The described experiences are based on 20 years of investigation of coastal dunes on the Polish Baltic coast, with additional data originating from other field investigations of many global coastal areas.
\end{abstract}

Keywords Foredunes $\cdot$ RTK $\cdot$ TLS $\cdot$ Equipment comparison $\cdot$ Dune surveys

Tomasz A. Łabuz

labuztom@univ.szczecin.pl

Institute of Marine and Coastal Sciences, University of Szczecin, Mickiewicza 18, 70-383 Szczecin, Poland

\section{Introduction}

With an increasing danger to coastal environments stemming from different sources, it is important to bear in mind how the present dune environment is developing under natural and human pressures. Currently, coastal dunes remain under research, as they are very dynamic environments, important for human use and management. Foredunes, which are mainly unstable, longitudinal coastal sand forms (Hesp 2002), are indicators of the accumulative character of the coast. The elevation and relief of those forms are extremely variable over short periods but can affect the coastal dynamics over a period of several years. The dynamics of sand volume building foredunes is an indicator of short-term coastal variability. The need for foredune relief studies is a component of the conservation aims that are urgent for coasts in changeable climate conditions.

There are several direct field and remote methods used by scientists in coastal dune research (Łabuz 2015). The field investigation methods may be divided as conventional survey using optical or laser equipment (Delgado and Lloyd 2004; Krause 2004; Andrade and Ferreira 2006; Khalil 2007) and digital GPS receivers reporting proper position in connection with a network of satellites (Andrews et al. 2002; Baptista et al. 2008; Harley et al. 2011; Jeong-Min et al. 2013; Montreuil et al. 2013a).

\section{Types of ground-based methods in field dune surveys}

The existing methods of coastal dune measurement vary according to their particular use, which might include: a) advancement of technology, b) different relief shape, c) aim of measurement scale (surface and time), d) weather and sunlight 
conditions, e) cost of employed technique for measurement, $\mathrm{f}$ ) time available for measurement, and $\mathrm{g}$ ) available staff.

Those technical factors influence the selected techniques and chosen aims of dune measurement. Each one technique is characterised not only by the potential for measurement but also by the aims of the undertaken research. The main methods of field research are:

- simple optical measures using rods, measuring tapes, etc.,

- field leveling using optical or laser theodolite and levellers,

- measurements using satellite positioning with GPS or DGPS tools, and

- ground terrestrial laser scanning (TLS) of different plots and dune components.

The complements of such research techniques include the analysis of topographical maps, aerial photos, field photography, and video. Airborne, remote methods are becoming more popular because they offer more accurate data and cover larger coastal areas. However, remote research does not allow the determination of how foredune environments change over a short time or during extreme events that may occur, especially when those events are becoming more frequent. Therefore, a number of ground-based research methods are being developed. The increased need for field investigation remains important to record features including short-term elevation change, form growth, or extreme event impact (Harley et al. 2011). The beginning of their use on coastal dunes and the usefulness of these techniques is presented in Table 1.

The careful selection of available ground-based survey methods varies according to specific field conditions, such as:

- longitudinal relief area in very narrow belts,

- very dynamic surfaces, changing in a short time and on short distances along the coast,

- unstable surface needing to be fixed for measurement tools,

- changeable weather conditions, e.g. in Poland, almost one-third of the year is characterised by rain, freezing conditions, heavy winds, stormy events, and short days (and conditions will vary by geographical location), and

- need for short-term research for public application of the results: coastal land dynamics and potential threats to the infrastructure from the sea or the rate of the erosion of dunes.

Table 1 The utilities comparison of main surveying methods in coastal dunes (Labuz 2015, completed)

\begin{tabular}{|c|c|c|c|}
\hline $\begin{array}{l}\text { Equipment for various } \\
\text { morphological field } \\
\text { measures }\end{array}$ & Beginning of use & $\begin{array}{l}\text { Varied accuracy of environment parts as buildings, } \\
\text { vegetation habitats, dune relief and beach changes, }\end{array}$ & Bigger areas surveys, e.g. whole sandbars \\
\hline $\begin{array}{l}\text { Simple: measure tape, } \\
\text { rods, or Emery } \\
\text { techniques }\end{array}$ & Since 1940s' & $\begin{array}{l}\text { Very small area, point relief measurements } \\
\text { and vegetation distribution }\end{array}$ & Simple information, point measure \\
\hline $\begin{array}{l}\text { Traditional optical } \\
\text { leveling }\end{array}$ & Since $1950 s^{\prime}$ & $\begin{array}{l}\text { Small area relief measurements } \\
\text { and vegetation distribution }\end{array}$ & Simple information, profiling \\
\hline Electronic leveling & Since 2000 & $\begin{array}{l}\text { Small area relief measurements } \\
\text { and vegetation distribution }\end{array}$ & More info, quicker data \\
\hline Simple laser leveler & Since 2002 & $\begin{array}{l}\text { Small area relief measurements } \\
\text { and vegetation distribution }\end{array}$ & Better for point accuracy measure \\
\hline $\begin{array}{l}\text { DGPS and RTK GPS } \\
\text { technique }\end{array}$ & $\begin{array}{r}\text { Since } 1995 \text { and RTK } \\
\text { widely since } 2002\end{array}$ & $\begin{array}{c}\text { Mainly relief changes, volume and height, } \\
\text { vegetation location, coastline changes }\end{array}$ & $\begin{array}{l}\text { Area size up to } 0.03 \text { sq. km per day, } \\
\text { long time of survey, availability of } \\
\text { satellites or AGN ground bases, forest, } \\
\text { weather }\end{array}$ \\
\hline Total Station (TS) & After 2000 & Mainly relief changes, each object location. & $\begin{array}{l}\text { Area size up to } 0.02 \text { sq. km per day, long } \\
\text { time, weather, relief complexity }\end{array}$ \\
\hline $\begin{array}{l}\text { Terrestrial Laser } \\
\text { Scanning (TLS) }\end{array}$ & $\begin{array}{l}\text { End of } 2000, \text { widely } \\
\text { since } 2005\end{array}$ & $\begin{array}{l}\text { Very high accuracy, digital data of dunes sand } \\
\text { volume dynamics, relief changes, object location, } \\
\text { just 3D image of environment }\end{array}$ & $\begin{array}{l}\text { Vegetation (grasses to trees), weather } \\
\text { (strong wind, rain). Range of } 50 \text { to } 800 \mathrm{~m} \\
\text { from the laser position }\end{array}$ \\
\hline Mobile DGPS & Since 2005 & Mainly for beach relief, volume and width & Relief of terrain, not adequate for dunes \\
\hline Mobile (TLS) & After 2010 & $\begin{array}{l}\text { Mainly for beach relief, volume and width, } \\
\text { also other object will be registered }\end{array}$ & $\begin{array}{l}\text { Relief of terrain, not adequate for dunes, } \\
\text { weather, vegetation }\end{array}$ \\
\hline Smartphone GPS & New in 2012 & $\begin{array}{l}\text { Forms position, plants positions, } \\
\text { measurements, cooperation with other } \\
\text { devices. Not clear }\end{array}$ & $\begin{array}{l}\text { Probably size of surveyed area } \\
\text { and data sets. Not clear }\end{array}$ \\
\hline $\begin{array}{l}\text { Mobile or fixed video } \\
\text { cameras and } \\
\text { imagery }\end{array}$ & Since 2000s' & Mainly permanent beach changes & $\begin{array}{l}\text { Observed small area, difficult analysis } \\
\text { and image processing }\end{array}$ \\
\hline
\end{tabular}




\section{Ground-based methods in foredune environment surveys}

In Poland, dunes cover almost $85 \%$ of the coast, which is strongly influenced by natural and anthropogenic factors. The coast is covered with different dune types and has recently shown variable, often unpredictable, tendencies in their development. In Poland, research has been lacking to explain the use of field techniques in coastal dune research.

The aim of this paper is to review the equipment used for foredune ground surveying in different environmental conditions based on literature and on experience from the Polish coast. The recognition of morphological change and rate of foredune accumulation was the main purpose of this study. Related investigations have been undertaken since 1997.
Some of the employed methods and collected data have been described in separate articles (Labuz 2003, 2009; 2011; 2013; 2014a, b; Łabuz et al. 2012). During field measurements, geodesic tools were used as a leveller and 3D leveling was performed using a GPS RTK base. Some tests with ground laser scanning were conducted, as well. The main measurements depended on the leveling of the beach and dune ridges and checking the distances among the forms that had built the coastal profile. The techniques that were employed varied over time, partially due to the accessibility of new tools and the possibility of their use. Some of them were in use since the beginning of dune measurements. Some were used occasionally, to check their accuracy in field research (as laser or code/ digital leveller, TS, and TLS). Figure 1 presents pictures of devices employed during fieldwork on Polish coastal dunes

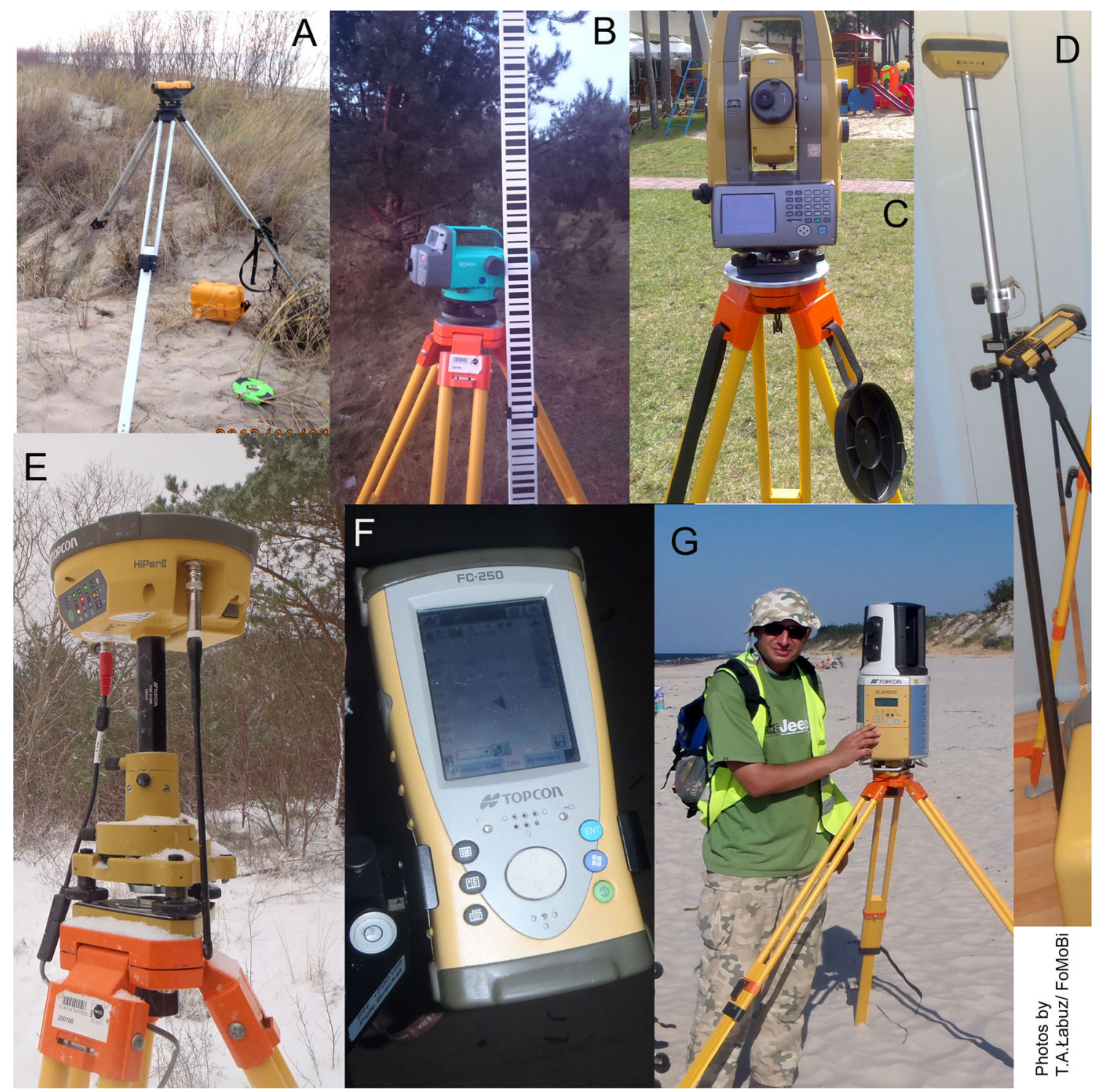

Fig. 1 Field measurement devices used during tests and fieldwork on Polish coastal dunes. a optical leveler N1 20. b electronic leveler Sokkia SDL50 with special measure pole. c Total Station (TS) IP 65 (waterproof). d mobile GPS RTK Hiper SR, receiver with controller on rod. e DGPS RTK station receiver-Hipper II. f part of DGPS device, RTK rover controller. g TLS scanner-GLS 1500 
since 1997. Laboratory computation of data depend on the aims and surface scale of each investigation. Several software programs have helped in the analysis of these data. Some of them were provided by companies supplying the equipment, and others by companies producing specialised software.

\section{Simple optical techniques}

This group of techniques and employed equipment allows for the measurement of relative heights in relation to the "reader" - the device that reads relative height differences between the points of interest. Knowing the actual height of a point where the device is located, the reader can determine the real and actual height differences between points at which the measurement was performed, e.g. using rods/poles, measuring tape, or even additional light (Fig. 2). These techniques allow the measurement of relative altitude changes, which may be sufficient for temporary or short-term analyses of aeolian processes and relief changes. They are useful for measuring only point elevation in the field, but on small surfaces may be helpful for sand volume changes computed for each of the measured points (Labuz 2003, 2009). There is no expensive equipment that needs to be used in the field using simple measurement. This kind of measurement is slow, but is sometimes the only option available to use. The simple methods are used especially during extreme storm events, when other advanced tools cannot work properly, e.g. during strong wind action, sand transportation, and heavy precipitation, or when accessibility to a global positioning system is impossible (Andrade and Ferreira 2006; Łabuz 2015).

\section{Rod use in field}

Rods may be used for reading of surface height changes. This technique has been used for 1.5 year study in cross-sections located across developing foredune (Labuz 2009). The reading of rod height that is fixed on an unstable surface reports height changes. Rods may be fixed in the ground within a distance of $1 \mathrm{~m}$ or in characteristic points of relief changes. Rods are helpful for relief measurements along profiles, crossing dune ridges, or to detect the growth of separate hillocks (Fig. 3). Rods can also cover known surfaces to read sand volume changes. On the Polish coast, this method was used several times to measure relief change inside $5 \times 5 \mathrm{~m}$ plots, along transects spanning dune ridges, and for embryo dune growth research. The longest period of research that has been conducted was 1.5 year long, with readings recorded every month (Figs. 2b and 3; Labuz 2009). The shortest investigations were conducted over the course of a few days, with readings taken every one or few hours. The technique of rod use in the field require the work of one person.

\section{Emery method}

The so-called Emery Method (Emery 1961; Delgado and Lloyd 2004; Harley et al. 2011) is based on two rods with marked scales. Placing them on different surface
Fig. 2 Useful techniques marking measured area. a transect marked by sticks across embryo dune. $\mathbf{b}$ surface plot marked in net by rods each one meter on foredune. c surface square plot marked by measure tape on embryo dune. $\mathbf{d}$ additional light after dusk marking embryo dune ridge for GPS RTK measurement

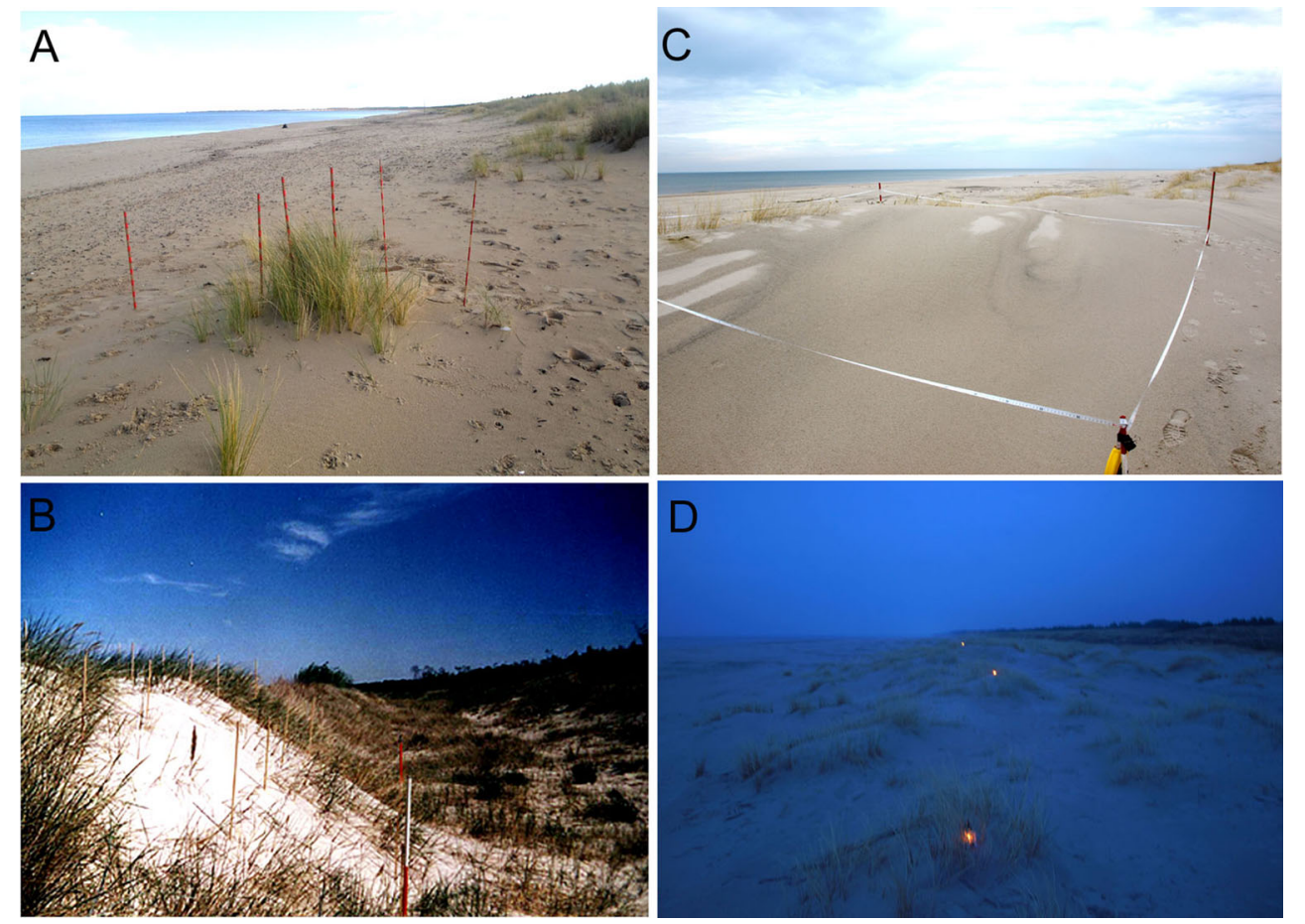


Fig. 3 The results of the shortterm foredune relief height changes obtained by rod measurements, every $1 \mathrm{~m}$ of the profile in period of 1.5 year. a the mean monthly elevation changes. b scale of the elevation changes (dynamics). $\mathbf{c}$ balance of the height changes (after 1.5 year). d profiles localisation and relief (the pile no. 5 to 9 is south dune slope, 10 ridge top, 11 and more is north dune slope), Swina Gate Sandbar, 420.6 km (Labuz 2009)

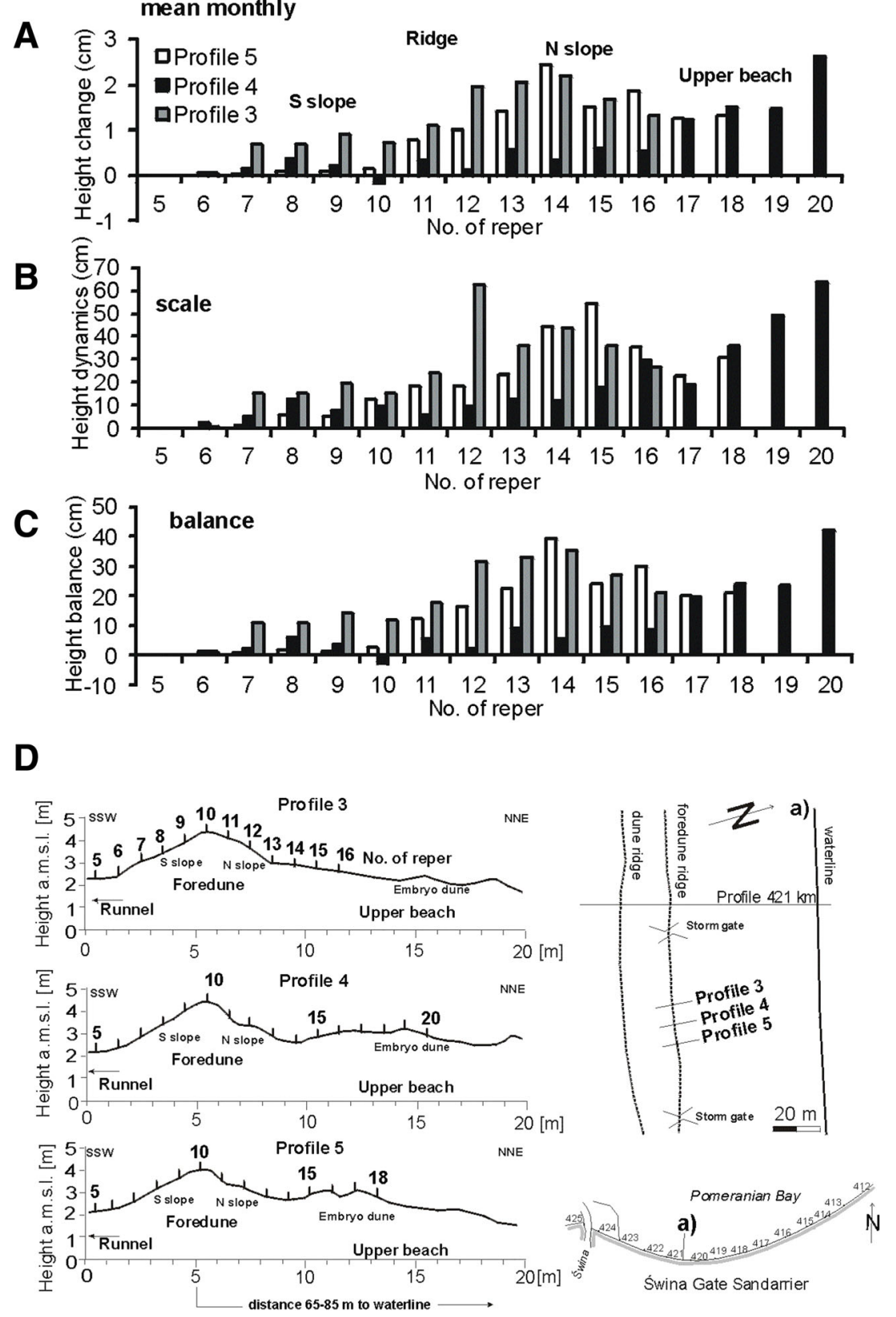

elevations, we can read the height between two points. With these rods being held vertical, the horizon can indicate the difference in elevation between the two positions. The distance between rods is measured by metric tape (Krause 2004). This method was and still is used for surveys of short-term morphology changes on Polish dunes (Labuz 2003, 2009). There are several other tools for this kind of research, including two connected tubes with water inside, where the water table shows the height differences (Andrade and Ferreira 2006). These methods require the work of two people.

\section{Equipment for optical measurements}

There are several conventional devices that can be used for optical measurements. They were popular in the 1980s, and have remained useful in the field during hard weather conditions. The optical topographical measurements are best for linear or point measurements. Among them are levellers and theodolites. Surface measurements performed by means of conventional methods still provide information about topographic and volumetric changes of dune areas that can then be used for 2D and 3D mapping (Andrews et al. 2002). 


\section{Leveller}

One of the oldest conventional geodesic methods depends on leveller measurements. This optical device with measuring pole is used to record relative elevation changes on small surface plots (measure of points of known distance) or along transects crossing relief forms, e.g. dune ridge, runnel, deflation hollow, or beach width. The lenses of the levellerleveller are fixed at one height, so the device must be moved when the elevation is larger than the pole height, e.g. foredune cliff slopes more than 5-7 m high. This method provides only distances and elevation differences among profiles. It is based on elevation reading that is shown on a pole scale. To achieve the easiest measurements, wooden rods should be used (painted red and white with the scale, e.g. $10 \mathrm{~cm}$ of each color) that are located in areas of surface change, such as dune top, foot, water line, or foot outline of embryo dune. Having these rods, a person with a measuring pole knows where the next measurement should be taken. This method is optical, and data need to be written on separate, prepared sheets of paper with additional information about weather conditions or measured relief sketches. Repeated measurements are performed from stable surfaces on dune hinterlands, through mobile forms. There is positioned a minimum of one rod, from which measurement starts. With two measurement rods, the azimuth transect can be quickly determined. This method is very simple, but requires the effort of two people. It can also be used on rainy days and also at night. Measurement during dusk or night needs to be done with artificial light, which can illuminate the scale on the pole. This traditional method of beach and dune monitoring through profiles perpendicular to the shoreline has low accuracy because there are areas between profiles that are impossible to record (Andrews et al. 2002). However, optical leveling of foredunes and other sandy coastal forms is a fast and easy method. Repeated measurements along the same profiles provide dynamic layers of a surface: the maximum and minimum elevation changes between measurement periods. On the Polish coast, this kind of
Fig. 4 The procedure of sand volume calculation of the relief form based on the profile crosssection. a morphodynamic bars, presenting the height change obtained on the basis of profile digitization. b superposed profiles, showing the dynamic layer and changes in terrain (profile H 3-29 km Hel Peninsula)

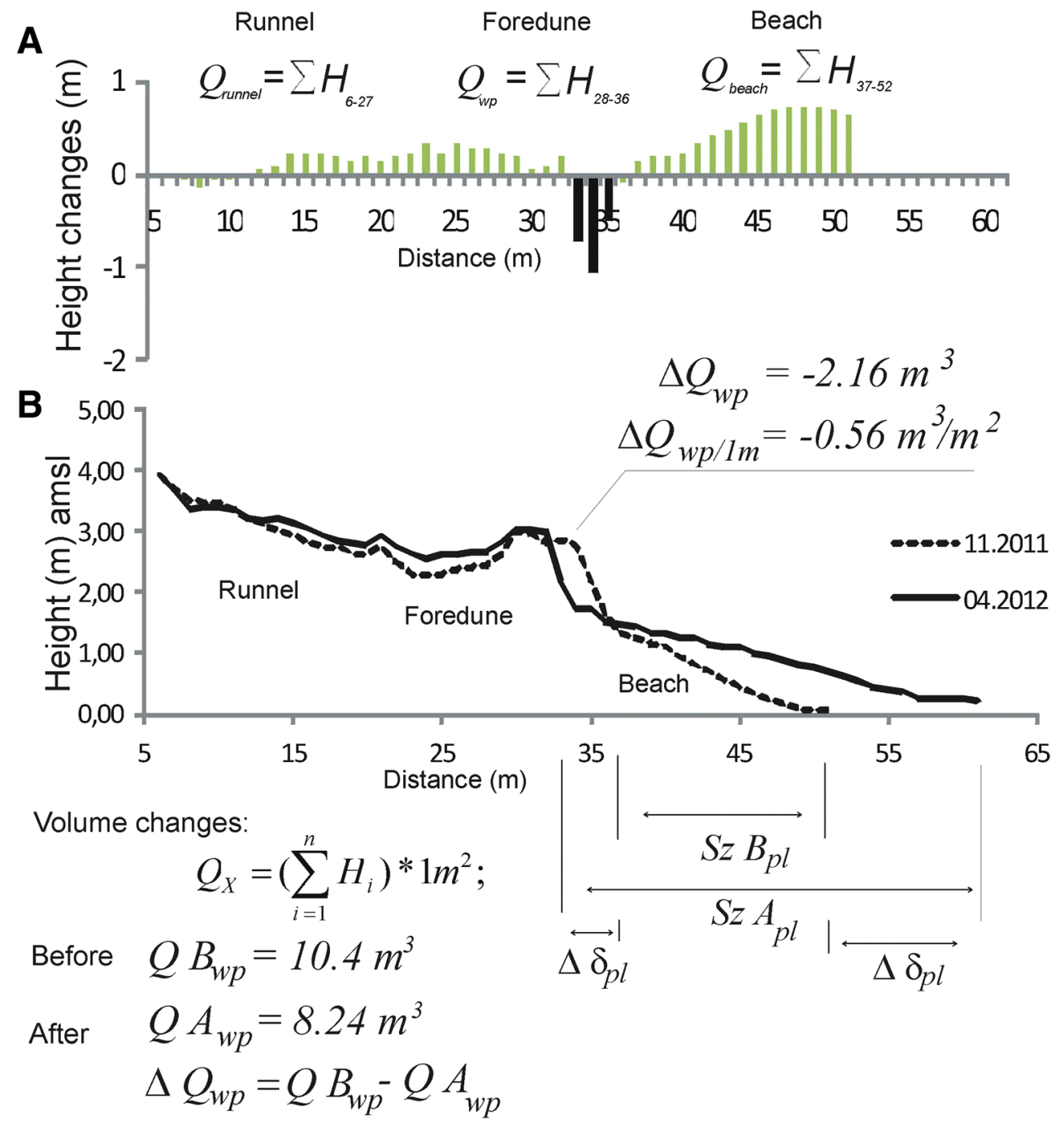




\section{A Foredune development}

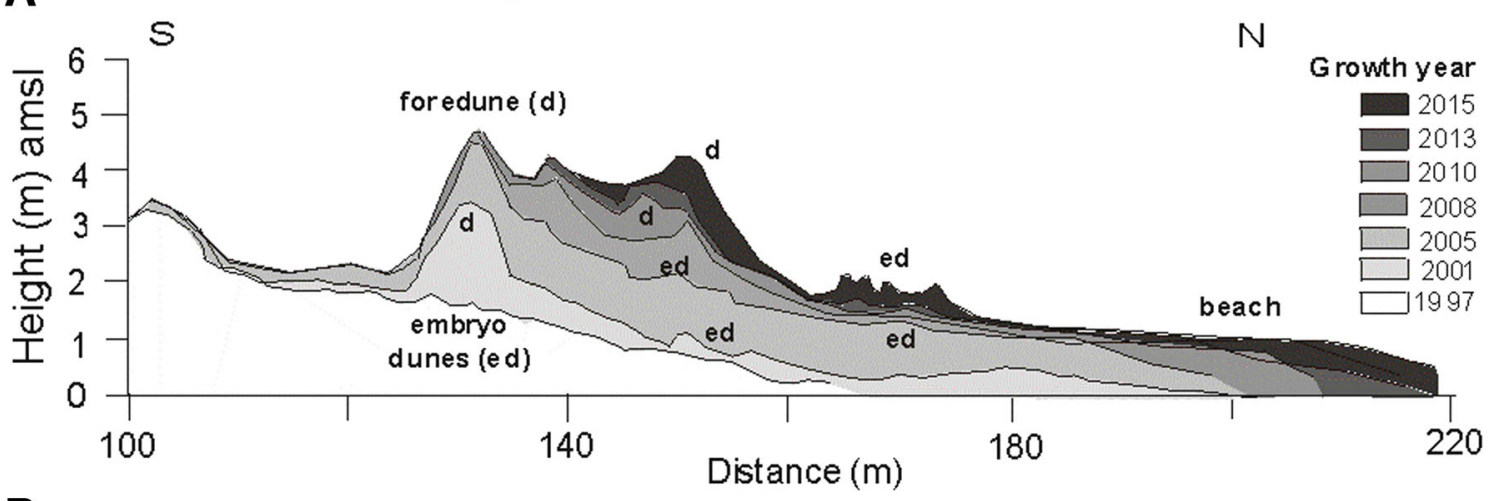

B

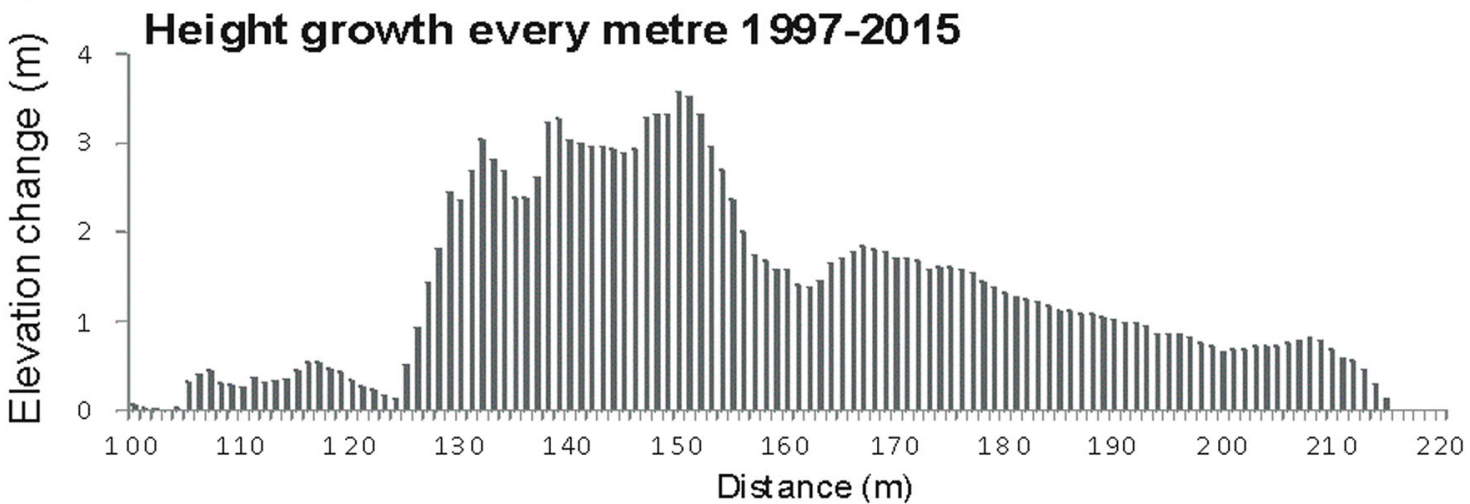

Fig. 5 Profile dynamics based on optical level measurements (19972014). a relief dynamics, each line - one measurement Main periods relief change periods are marked. $\mathbf{b}$ morphodynamics bars, presenting elevation change every meter (based on digitalization method) in period 1997-2014 (Swina Gate Sandbar, 421 km)

location, where I conducted surveys on storm erosion. In this case, measurements were collected as frequently as several times per day (Labuz 2011). One of the longest investigational
Fig. 6 Embryo dune relief changes and 3D accuracy in plot measurement, example of accuracy measurement of the surface plot (size: $5 \times 5 \mathrm{~m}$ ) that is done using two surveying techniques. a plot made using a optical level with altitude readings at $1 \mathrm{~m}^{2}$. b plot made using RTK GPS with readings each few $\mathrm{cm}$; we 1 , we 2 embryo hillocks. $\mathbf{c}$ plot relief in 06.2009. d plot relief in 12.2014

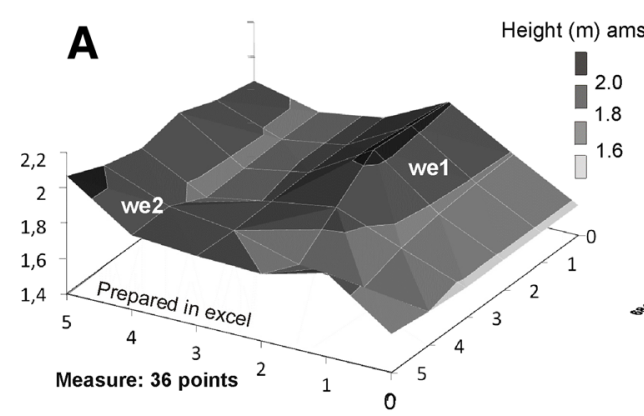

B

B Height (m) ams
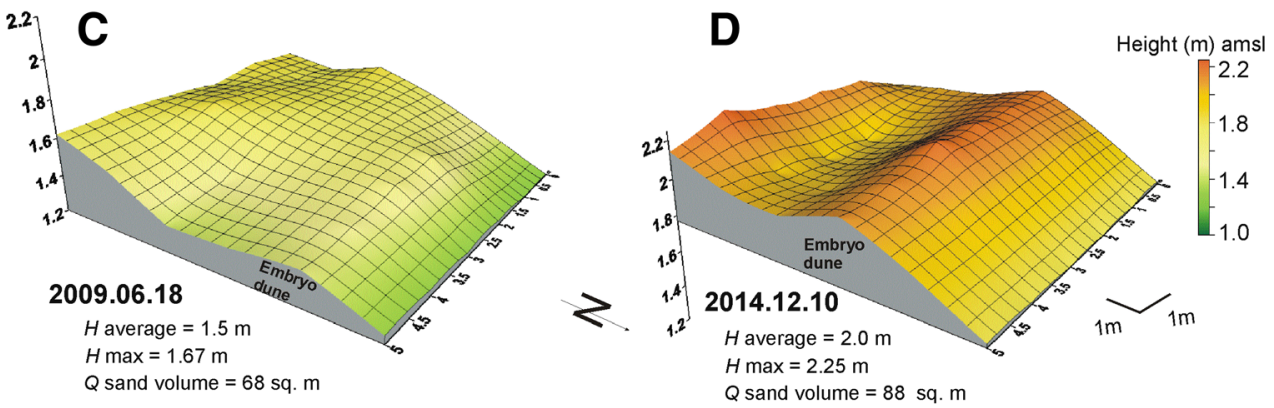
periods using a leveller is described by Hesp (2013); the duration has extended for 34 years, so far. On the Polish coastal dunes, I have conducted research using a leveller for the last 17 years (Fig. 5; examples: Łabuz 2009, 2013). The elevation data along profiles may be extrapolated for sand volume changes along a profile (Fig. 4) or in a plot (Fig. 6). These data can be used for the determination of elevation changes, form movement (e.g. dune foot, beach width, etc.), or sand volume changes along a profile or in each separate relief form: foredune ridge, embryo dune, beach, etc.

\section{Theodolit}

This optical tool provides similar data as an optical levellerleveller, but the data are more accurate due to the angles read by the device. Angle measurement and a movable lens are advantages when measuring elevations higher than the length of the measuring pole. The measurements of the points can be done freely on a surface, but still require more time to write analog data. This technique is not popular in coastal measurements because this device is usually heavier and more delicate than a leveller. The author used it only at the beginning of the coastal investigations on the Swina Gate Sandbar in 1997/98 for establishing the rate of embryo dunes development (Łabuz 2003).

\section{Equipment for automatic measurements}

Various digital automatic devices are used in geodesy. These devices range from a digital or laser leveller to a Total Station, which is a new version of the theodolite. Measurements by these devices depend on the digital reading and digital writing of the collected data in the device's memory. With the greater speed, accuracy, and the automation capabilities of digital measures, these devices are expected to replace manual leveling procedures (Radcliffe 1999).

\section{Laser leveller}

The laser leveller device consists of a laser transmitter and a sensor fixed on a typical geodesic pole or measuring pole. The transmitter device must be fixed close to the area that will be measured. The distance of the laser reading is in the range of 100-300 $\mathrm{m}$ around the leveller. Measurements should be taken at known distances between the laser and pole. Alternatively, measurements can be collected at each individual height reading by, for example, measuring tape. This method is still the best for the measurement of transects or points. Changing weather conditions, or high bushes or trees, can reduce the measurement's accuracy. The laser leveller device is mainly for use by two people, but it can be used by a single person.

\section{Electronic leveller}

The electronic leveller, also called the code leveller, is a solution for digital-optical leveling. This device virtually eliminates reading errors and automates the collection of data. Also, field work is conducted more quickly with digital reading than with conventional methods. This kind of device, produced by Sokkia (SDL 50), was also tested for typical profiling of the dunes and beaches on the Polish coast (Fig. 1b). It can be used both for conventional readings and electronic ones, where data are stored on a memory card added to the device. Through a standard optical telescope and camera, the digital data are obtained from a specialised measuring pole. This pole has a scale that is represented by a series of bars of different widths. The scale does not repeat along the face of the rod. Thus, the pattern and the relationship of the pattern to the adjoining patterns are unique for every group of bars on the pole and is important for controller reading (Radcliffe 1999). The reading is based on light recognition from bars by a charge-coupled device (CCD) matrix positioned in the device. This CCD matrix is an arrangement of light-sensitive elements that capture light and transform it to an electrical signal that is proportional to the amount of light. The controller from the device uses this signal to detect a height difference when the measuring pole is moved to another place. The accuracy of height measurement is better than $0.1 \mathrm{~cm}$, but distance measurement from the device to the pole varies due to sunlight operation. The maximum sighting distance should not exceed $300 \mathrm{~m}$ in good measuring conditions, with the bar code magnified by $4 \times$ (Khalil 2007). Trigonometric leveling can be used for third-order leveling with maximum sighting distance of $100 \mathrm{~m}$ (Khalil 2007). The leveller firmware is useful both for elevation and distance measurements among the points. That is why this instrument can be used for the measurement of points scattered around the device. This device needs to be operated by two persons.

\section{Total Station (TS)}

Total Station (TS) is an electronic theodolite integrated with an electronic distance meter (EDM). It includes a reflective mirror that allows the researcher to measure the angle and distance coordinates $(x, y, z)$ from the measurement tool to the area under survey (Fig. 1c). This method allows the measurement of height, distances, and angles among measured points. For this reason, measured points can be selected freely. The usage of this technique is more flexible and permits the faster collection of data for elevations on surface areas (not only transects or scattered points). However, the preparation process for these measurements takes more time than the other methods because it requires software setup to collect digital data. These surveys should be done in the real-world coordinate system (Kizil and Tisor 2011; Khalil 2013). The weather 
may pose a problem when using TS, because rain or snow can interfere with the light emitted from the TS emitter. The Total Station is a widely used tool to survey land form evolution and to monitor land use (Khalil 2013) as well as beach dune ecosystems (Delgado and Lloyd 2004; Baptista et al. 2008; Harley et al. 2011). It is also employed to measure shortterm dynamics (Anfuso et al. 2007). This device needs to be operated by two persons.

\section{Satellite positioning methods in field use}

The common way to perform very high-accuracy GPS measurements is based on satellite positioning networks. There are several Global Navigation Satellite Systems (GNSS) networks: the American Global Positioning System (GPS), the Russian Global Navigation Satellite System (Globalnaja Nawigacionnaja Sputnikowaja Sistiema-GLONASS), and the constantly developing European Galileo satellite system, as well as Chinese and Indian ones. Since the satellite positioning systems became operational, field GPS measurements have become faster and easier, and accuracy has improved. There are several geodesic devices that can directly measure dunes for Geographical Information System (GIS) mapping. Among them are simple GPS research techniques intended to examine the location of measured areas, or advanced tools saving ground data in three dimensions $(x, y, z)$. The next generation measures yield very accurate position data in the field. Presently, the majority of GPS receivers in Europe are based on the American and Russian satellite networks. The use of this method is based on the accessibility of satellites for devices working in field tools that are related to geographical coordinates.

\section{GPS measurements}

Measurements based on the location of investigated areas with the use of popular GPS receivers mark the beginning of modern topographical surveying. Initially, GPS had provided only two-dimensional data $(x, y)$, corresponding to the geographical position of an area or point. These devices measure the time of arrival of a radio signal from satellites to the receiver. The GPS signal information depends on the layout of satellites in the sky and their theoretical paths, as well as their deviations from those paths (the so-called ephemera). Using "trilateration"-measurement of three points in a triangular tied system - the receiver can calculate the geographical position: longitude, latitude, and ellipsoidal altitude, and then send it to the selected reference system.

\section{Real-Time Kinematic (RTK) GPS}

The most famous measures are based on a technique called the Differential Global Positioning system (DGPS). The DGPS involves the cooperation of ground-based DGPS reference mobile receiver stations (Fig. 1e, f), mobile rovers, and satellite networks. The two wireless communicating receivers, one with known position and another mobile, provide the coordinates of measured points compared with the known position in the field. The combination of these techniques is called RealTime Kinematic (RTK) GPS. The RTK-DGPS is a technique used world-wide for beach and dune surveying (Fig. 7),
Fig. 7 The devices at work. a DGPS mobile RTK part of Hiper II. $\mathbf{b}$ receiver and controller of mobile GPS Hiper SR. c scanner GLS 1500 with laptop for data acquisition. $\mathbf{d}$ field instruments for laser scan acquisition: $a$ ) back point on dune, $b$ ) scanner on beach, $c$ ) front point near water line. e close view of used points during scanning
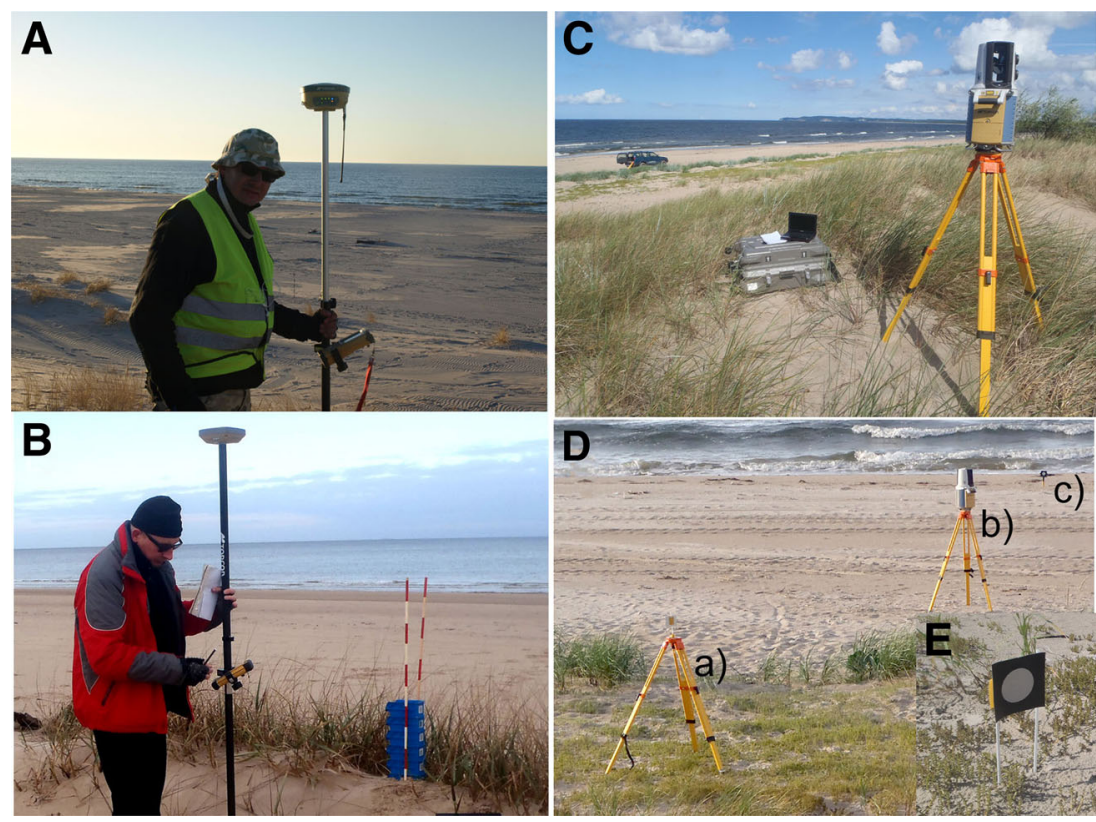
(Pardo-Pascual et al. 2005; Dornbusch 2010; Lee et al. 2013). This technique is also based on a ground network: the Active Geodetic Network (AGN) consisting of several fixed ground bases referenced to a global satellite system. Several countries have been developing such bases. In Poland, the government base developed by the National Geodetic Service is reinforced by the corporate network, such as Topcon. Currently, each country has or will have such a network, which can also be used for other purposes.

The communication between a measuring device in the field and an AGN transmitter can be realised through the Internet or a cellular network. Therefore, there are portable GPS RTK receivers called rovers that can communicate over a cellular telephone network with the nearest base transmitting corrected coordinates. In areas where there is no AGN network, the GPS rover measurements without ground-base are not possible. After the first experiments with the DGPS RTK - a mobile base and a rover for obtaining coordinates of points located on partly forested and secluded coastal dunes - a local coordinate network was established and was based on a local triangular network.

Taking into account the above information, we can recognise, two types of GPS-RTK methods:

- Differential Global Positioning System: this consists of RTK (DGPS RTK) stations and two receivers. One receiver is a stationary/stabilised ground-based reference station to broadcast the difference between the positions indicated by the satellite systems and the known fixed positions. The other receiver is a rover used to rove around, making position distance measurements from the base (Fig. 1e, f).

- Real-Time Kinematic (RTK) GPS: a single RTK rover that is independent from the field ground base but communicates with an AGN network through a cellular phone network (Fig. 1d).

Both techniques provide very accurate point data from field measures. Those techniques are independent from local geodesic networks. It is a quite fast method to register dune and beach relief changes for different surfaces and time scales. This method requires one person to work, but having two is more helpful, e.g. to start up the device, perform demarcation of the measured area by rods (very helpful during measurement), and draw the surface sketch. The reading depends on rover fixation at the needed point of the measured place. The set of points with known coordinates recorded by a receiver may be processed in the relief model or image by specialised software. The working time of devices in the field depends on the length of the batteries' operation. A typical batterypowered receiver works for only approximately $8 \mathrm{~h}$. Nonideal meteorological conditions (coldness, wind, rain) shorten battery life. This is why a DGPS base can be equipped with a long-life car battery. To improve the quality of the work when using the RTK-GPS system, the proposed optimum reading interval between points is $20 \mathrm{~cm}$ (Kizil and Tisor 2011). Higher reading resolutions become unproductive (PardoPascual et al. 2005; Lee et al. 2013). The accuracy mainly depends on relief diversity (Labuz 2015). A large proportion of errors may either be made by an operator or can be the result of an unexpected movement of the equipment during operation (Lee et al. 2013). Moreover, it should be underlined that this accuracy depends on the relief diversity, mainly of small embryo dunes, that needs to be measured in more detail (Labuz 2015). Until recently, the margin of error when reading the exact height by means of GPS was almost $20 \mathrm{~cm}$. Currently, we can do this with the precision of a few millimetres, depending on the user's skills.

The GPS survey data are usually transformed to a geographic information system, where scattered points are converted to profile lines or 3D surface models. The repeated measures of the same area can be compared in specialised software (Fig. 8). Advanced analyses such as elevation change and volume dynamics can be investigated. The research on Polish dunes with this method was initiated in 2012 (Fig. 7). The procedure of continuous research in the field that considers difficult weather conditions has been prepared (Łabuz et al. 2012). For the device to operate, two persons is the minimum requirement, but for short investigations, one is sufficient.

\section{Mobile use of GPS RTK technique}

Another surveying technique entails the RTK-GPS system being mounted on an all-terrain vehicle (ATV). This method is widely adopted for efficient surveys having a wider spatial coverage compared with on-foot GPS surveys (Pardo-Pascual et al. 2005; Baptista et al. 2008; Lee et al. 2013). The accuracy of measurement is based on the speed of the vehicle, e.g. quad. This method is only used on beaches, due to the readout noise caused by changing elevation. Such a system can be equipped in several RTK GPS receivers, but requires more work for operation.

\section{Digital terrestrial surface laser (TLS)}

There are different ground scanners operating in varying conditions, such as the Terrestrial Laser Scanner (TLS) and the Mobile Laser Scanner (MLS). The terrestrial fixed scanner is able to collect the point data at a $360^{\circ}$ angle range around the positioned equipment. The mobile version contains four lasers fixed on the vehicle. This is possible in Poland by having a car and related devices developed by the company Topcon Poland. The parameters of such an investigation on dunes have been discussed. The only problem is the shape of dune 
Fig. 8 Foredune and beach relief acquired from GPS RTK measurement (size $50 \times 100 \mathrm{~m}$ ), in autumn of 2012 and 2014, Vistula Sandbar, Jantar, $43 \mathrm{~km}$ (based on surfer software). a 3D model of both periods. $\mathbf{b}$ maps of both periods. Grey height scale is in meters

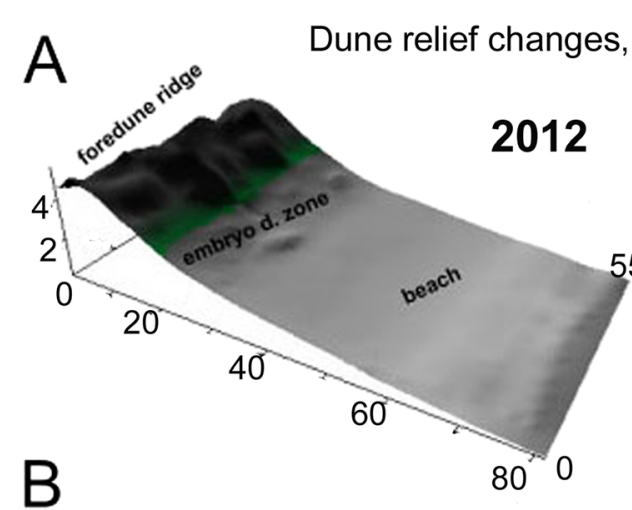

Dune relief changes, Vistula Sandbarrier, Jantar 43 km

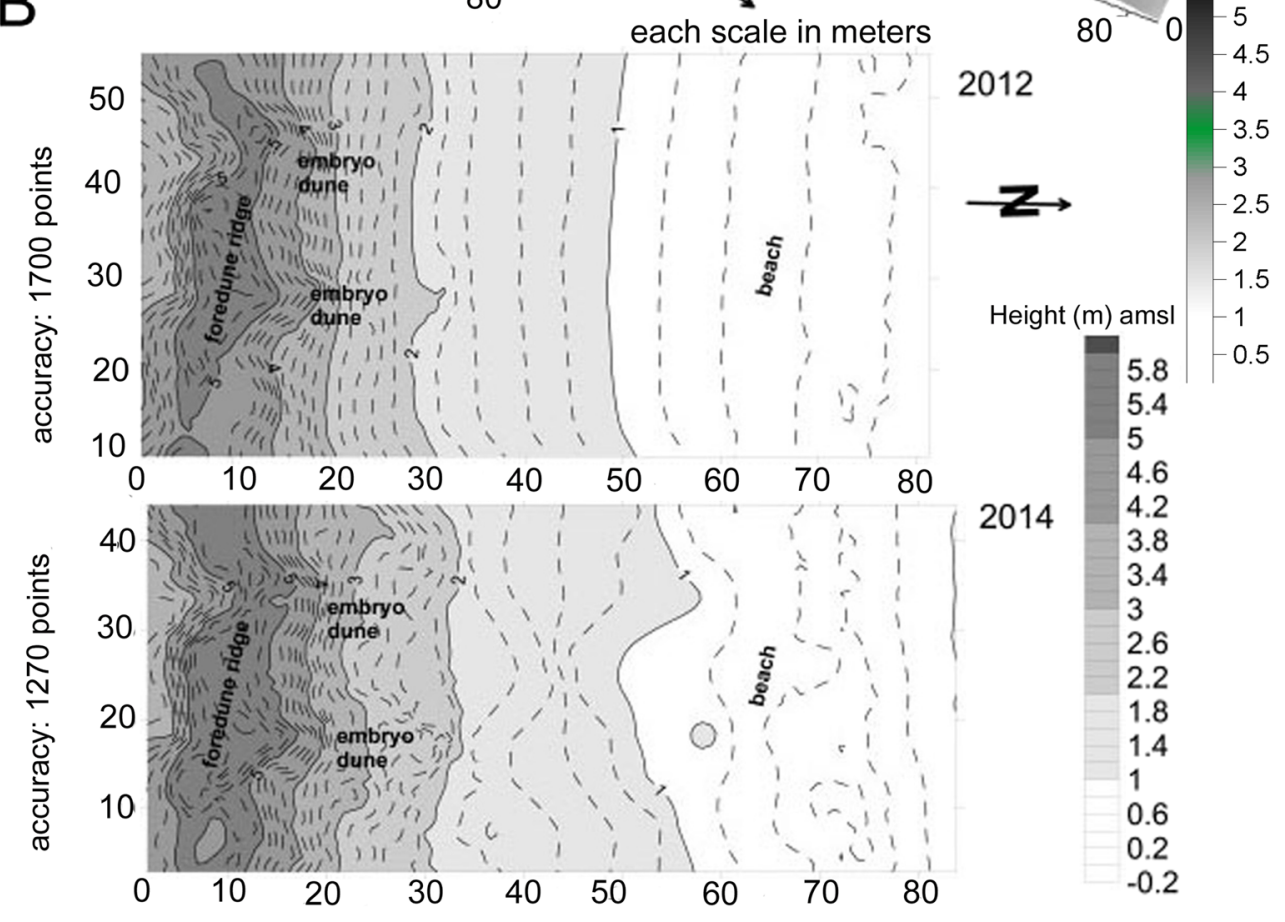

relief: they cannot be crossed by car, only by quad (and additional permits are required).

\section{Ground terrestrial surface laser}

The laser scanner allows measurements without interfering with the sand surface, which occurs when surveying is performed using other equipment such as GPS RTK or Total Station. The range of a scanner depends on its technical parameters and assignment (Pilecki 2012; Montreuil et al. 2013b; Michoud et al. 2013). For example, the Optech scanner can measure surfaces at a distance of $800 \mathrm{~m}$. The smaller Faro scanner is suitable for the measurement of small surfaces located in close proximity, ranging up to $80 \mathrm{~m}$ from the instrument. The equipment supplied by Topcon enables measurement within approximately $150 \mathrm{~m}$ from the scanner and up to $100 \mathrm{~m}$ from a Leica ScanStation. The Topcon GLS 1500 (Fig. 1g) and Leica Scanmaster were used on Polish coastal dunes (Łabuz 2014b).
The measurement procedure is dictated by the investigated area and its shape. The embryo dunes on a beach can be scanned-measured from one position of a laser. The foredune ridges need to be scanned from two or more sites, varying the exposition of slopes. Small surfaces with one ridge should be scanned from two positions. The longitudinal relief form needs to have several scans on both slopes. The scan of the beach is most accurate from its middle, giving surface information around the scan laser emitter. This device can be used by one person, but is delicate and heavy. It cannot be used during strong wind action or during rain. Investigation during nighttime is no problem. However, the main problem is vegetation covering the scanned surface. Laser light cannot pass through vegetation. For this reason, data from vegetated areas should be processed with additional transformation.

Scan accuracy depends on the scanned distance from the area and the predetermined number of points per unit area. The sampling rate is as high as 50,000 points per second (Montreuil et al. 2013b). After 30 min, the data set 
Fig. 9 Image of foredune and embryo dune relief based on scanner (TLS) measure, Rowy, $219 \mathrm{~km}$. White points show density of scanner accuracy used at work (based on one scanner position)

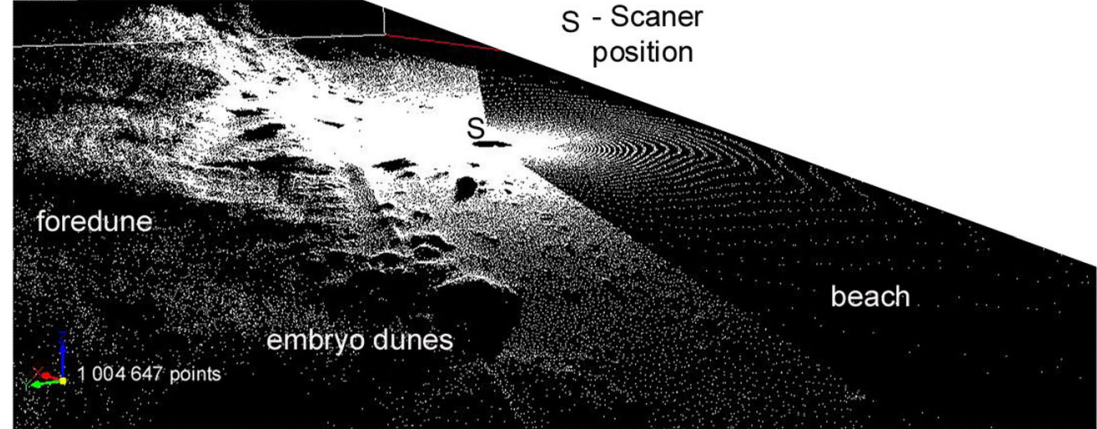

Resolution accuracy scan of dune $3 \mathrm{~cm}$
Resolution on lower beach $10 \mathrm{~cm}$ can completely cover an area with a distance of 1-3 cm. The point data set of "cloud data" of the collected $x, y, z$ variables can be imported into various software packages including GIS or other software. The laser scanner can be used to measure seasonal relief changes of embryo dunes or dune fronts (Feagin et al. 2012; Montreuil et al. 2013a, b). The best use of this device is on the beach and upper beach with foredune slope, where plants do not disturb the data collection (Fig. 9).

\section{Mobile terrestrial surface laser}

Mobile terrestrial laser scanning is an emerging technology that combines the use of a laser scanner and a global navigation satellite system. The newest development involves those devices being fixed on a mobile platform. Ground-based mobile laser systems are typically installed on a quad, minivan, or boat. The mobile scanner allows measurements without interfering with the sand surface, which occurs when surveying is

Table 2 Comparison of methods and possible field measures in relation to obtained morphological data

\begin{tabular}{|c|c|c|c|c|c|c|c|c|}
\hline Possible measure & Points & $\begin{array}{l}\text { Line, } \\
\text { profiles }\end{array}$ & $\begin{array}{l}\text { Relief of the } \\
\text { form }\end{array}$ & $\begin{array}{l}\text { Whole form } \\
\text { relief, surface }\end{array}$ & $\begin{array}{l}\text { Larger surface } \\
\text { with forms }\end{array}$ & $\begin{array}{l}\text { DTM model } \\
\text { of surface }\end{array}$ & $\begin{array}{l}\text { True record of } \\
\text { surface }\end{array}$ & $\begin{array}{l}\text { Sand volume } \\
\text { in forms }\end{array}$ \\
\hline $\begin{array}{l}\text { Simple measurements } \\
\text { (e.g. rods, Emery } \\
\text { method) }\end{array}$ & Yes & Yes & $\begin{array}{c}\text { Yes/only small } \\
\text { scale forms }\end{array}$ & No & No & No & No & $\begin{array}{l}\text { Yes/ only in } \\
\text { small ones }\end{array}$ \\
\hline Traditional leveling & Yes & Yes & Yes & No / too costly & No & No & No, only lines & $\begin{array}{l}\text { Yes/only in } \\
\text { small ones }\end{array}$ \\
\hline Electronic leveling & Yes & Yes & Yes & $\begin{array}{l}\text { Yes, small } \\
\text { areas }\end{array}$ & Yes & $\begin{array}{l}\text { Yes, small is } \\
\text { accurate }\end{array}$ & $\begin{array}{l}\text { No, only } \\
\text { points and } \\
\text { lines }\end{array}$ & $\begin{array}{r}\text { Yes/ points or } \\
\text { small areas }\end{array}$ \\
\hline Digital laser leveling & Yes & Yes & Yes & Yes/hard to do & No & $\begin{array}{l}\text { Yes, very } \\
\text { small }\end{array}$ & No, only lines & Yes/ points \\
\hline Total Station (TS) & Yes & Yes & $\begin{array}{l}\text { Yes, } \\
\text { time costly }\end{array}$ & $\begin{array}{l}\text { Yes, very time } \\
\text { costly }\end{array}$ & No & Not adequate & $\begin{array}{r}\text { No, only } \\
\text { points }\end{array}$ & $\begin{array}{l}\text { Yes/ small } \\
\text { ones }\end{array}$ \\
\hline $\begin{array}{l}\text { DGPS and RTK GPS } \\
\text { technique }\end{array}$ & Yes & Yes & Yes & $\begin{array}{l}\text { Yes/ time } \\
\text { costly }\end{array}$ & $\begin{array}{l}\text { Yes/ very time } \\
\text { costly }\end{array}$ & Yes & $\begin{array}{l}\text { No, but close } \\
\quad \text { of } 3 \mathrm{D}\end{array}$ & Yes \\
\hline $\begin{array}{l}\text { Terrestrial Laser } \\
\text { Scanning (TLS) }\end{array}$ & No & No & $\begin{array}{l}\text { Yes/after } \\
\text { advanced } \\
\text { computation }\end{array}$ & $\begin{array}{l}\text { Yes (and more } \\
\text { around) }\end{array}$ & $\begin{array}{l}\text { Yes (range } \\
\text { delimita- } \\
\text { tion) }\end{array}$ & Yes/ true one & $\begin{array}{l}\text { Yes/ true relief } \\
\text { (3D) }\end{array}$ & Yes \\
\hline Mobile DGPS & No & No & -“"- & $\begin{array}{l}\text { Yes/after } \\
\text { software } \\
\text { cut of offset }\end{array}$ & $\begin{array}{l}\text { Yes/ more } \\
\text { computa- } \\
\text { tion is need }\end{array}$ & $\begin{array}{l}\text { Yes/ more } \\
\text { computa- } \\
\text { tion is need }\end{array}$ & $\begin{array}{l}\text { Yes/ more } \\
\text { computa- } \\
\text { tion is need }\end{array}$ & $\begin{array}{l}\text { Yes/ more } \\
\text { computa- } \\
\text { tion is need }\end{array}$ \\
\hline Mobile TLS & No & No & -“" & -6 & 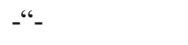 & -“- & -6 & -“- \\
\hline Smartphone GPS & Yes & Yes & $\begin{array}{l}\text { No (but under } \\
\text { tests) }\end{array}$ & No & No & No & No & No \\
\hline $\begin{array}{l}\text { Fixed video cameras } \\
\text { and imagery }\end{array}$ & $\begin{array}{l}\text { Only } \\
\text { picture } \\
\text { not } \\
\text { rectified }\end{array}$ & $\begin{array}{l}\text { Only } \\
\text { picture } \\
\text { not } \\
\text { rectified }\end{array}$ & $\begin{array}{l}\text { Only picture } \\
\text { not rectified }\end{array}$ & $\begin{array}{l}\text { Only picture } \\
\text { not rectified }\end{array}$ & No & No & No & No \\
\hline
\end{tabular}


performed using other equipment, such as a GPS RTK or a Total Station. It also permits larger areas to be measured.

\section{Other visualisation methods}

Complementary to the other field research methods are photographic or video images. Photography in geomorphology is a recognised method to obtain true pictures of measured relief. The TLS measure may also provide photographs of the scanned surface, and it is additionally helpful in postprocessing of the data. Video registration is used during visible surface changes, as in aeolian transportation or storm surge erosion. At present, mobile cameras are used in field research for different purposes. The Go Pro camera, having 4 to $8 \mathrm{~h}$ of video recording time, is protected against shock and rain, and yields high-resolution images and movies. It can be fixed on the researcher's head or chest, or on the measurement device. The obtained high-frequency data are helpful during laboratory computations and analyses.
The registration of beach and foredune dynamics using fixed cameras has been used since the 1990s (Silva et al. 2009). This is a fully automated procedure to derive mainly beach width and elevation changes on video images or movies collected on a daily basis (Holland et al. 1997; Uunk et al. 2010). In order to obtain quantitative information from these images, several devices must be used. Such cameras are now used in our institutes in Międzyzdroje and Dziwnów. This method requires the use of an image rectification procedure for measuring the observed relief changes. In combination with manual mapping by a conventional survey or DGPS, it may be a promising method for data collection for future computations (Uunk et al. 2010). However, single cameras are used for collecting information and predicting dune-beach changes related to extreme storm surges or to management for touristic purposes. Many such cameras are spread on the Polish coast. These were used for beach monitoring during the recent stormy events in December 2014 and January 2015. (This technique of reading will be described in a separate article).

Table 3 Comparison of methods and their characteristics accuracy

\begin{tabular}{|c|c|c|c|c|c|c|c|c|c|c|}
\hline $\begin{array}{l}\text { Accuracy } \\
\text { character }\end{array}$ & $\begin{array}{l}\text { Data } \\
\text { type }\end{array}$ & $\begin{array}{l}\text { Height } \\
\text { accuracy } \\
\text { range }(\mathrm{cm})^{\mathrm{a}}\end{array}$ & $\begin{array}{l}\text { Expertise } \\
\text { accuracy }^{\mathrm{a}}\end{array}$ & $\begin{array}{l}\text { Field accuracy. } \\
\text { Coverage hour or } \\
1 \text { day research }\end{array}$ & $\begin{array}{l}\text { Points data } \\
\text { per } \\
\text { measure } \\
\text { hour }^{\text {a }}\end{array}$ & $\begin{array}{l}\text { Plants } \\
\text { disturbance }\end{array}$ & $\begin{array}{l}\text { Night } \\
\text { research }\end{array}$ & $\begin{array}{l}\text { Time to } \\
\text { reach single } \\
\text { aim }^{\mathrm{a}}\end{array}$ & $\begin{array}{l}\text { No. of } \\
\text { working } \\
\text { people }\end{array}$ & $\begin{array}{l}\text { Cost/day/ } \\
\text { device } \\
(\text { EURO) }\end{array}$ \\
\hline $\begin{array}{l}\text { Simple } \\
\text { measurements } \\
\text { (e.g. rods, } \\
\text { Emery method) }\end{array}$ & $\begin{array}{l}\text { Points, } \\
\text { lines }\end{array}$ & $0.5-1 / 0.1-1$ & Low & $\begin{array}{l}\text { Line } 100 \mathrm{~m} \text {, plot } \\
\qquad 10 \times 10 \mathrm{~m} / 2 \mathrm{~h}\end{array}$ & $\begin{array}{l}1-50, \\
\text { scattered } \\
\text { or line }\end{array}$ & No & Yes & $1 \mathrm{~h}$ & $1-2$ & 50 \\
\hline $\begin{array}{c}\text { Traditional } \\
\text { leveling }\end{array}$ & $\begin{array}{l}\text { Points, } \\
\text { lines }\end{array}$ & $0.5-1$ & Medium & $\begin{array}{l}\text { Line } 250 \text { m long, } \\
\text { plot } 36 \text { sq.m } / \mathrm{h}\end{array}$ & $30-150$, line & No & Yes & $0.5 \mathrm{~h}$ & $2-3$ & 200 \\
\hline Electronic leveling & $\begin{array}{l}\text { Points, } \\
\text { lines }\end{array}$ & $0.1-0.01$ & High & -“- - n n n & $\begin{array}{c}\text { 100-200, } \\
\text { every } \\
\text { position }\end{array}$ & No & No & To $0.5 \mathrm{~h}$ & 2 & 300 \\
\hline $\begin{array}{l}\text { Digital laser } \\
\text { leveling }\end{array}$ & $\begin{array}{l}\text { Points, } \\
\text { lines }\end{array}$ & $0.5-1$ & Medium & $\begin{array}{l}\text { Line } 150 \mathrm{~m} \text {, plot } 36 \\
\text { sq.m/ h }\end{array}$ & $\begin{array}{c}\text { Up to } 200 \\
\text { around } \\
\text { device }\end{array}$ & Half/bushes & No & To $0.5 \mathrm{~h}$ & $1-2$ & 500 \\
\hline $\begin{array}{l}\text { DGPS and RTK } \\
\text { GPS }\end{array}$ & $\begin{array}{l}\text { Points, } \\
\text { lines }\end{array}$ & $0.1-0.5$ & $\begin{array}{l}\text { High / v. } \\
\text { high }\end{array}$ & $\begin{array}{l}\text { Wide plot } \\
\quad 60 \times 200 \mathrm{~m} / \text { day }\end{array}$ & $\begin{array}{l}200(300) \\
\text { dep. on } \\
\text { surface }\end{array}$ & $\begin{array}{l}\mathrm{No} / \text { forest } \\
\text { only }\end{array}$ & Yes & $\begin{array}{c}60 \times 100 \mathrm{~m} \\
12 \mathrm{~h}\end{array}$ & $1-2$ & $\begin{array}{c}5000-10 \\
000\end{array}$ \\
\hline Total Station (TS) & $\begin{array}{l}\text { Points, } \\
\text { lines }\end{array}$ & $0.1-0.5$ & High & $\begin{array}{l}100 \mathrm{~m} \text { line or } \\
10 \times 10 \mathrm{plot} / \mathrm{h}\end{array}$ & $\begin{array}{c}250-300 \\
\text { around } \\
\text { device }\end{array}$ & $\begin{array}{l}\mathrm{No} / \text { forest } \\
\text { only }\end{array}$ & No & $\begin{array}{l}60 \times 100 \mathrm{~m} \\
\text { more than } \\
1 \text { day }\end{array}$ & $1-2$ & 3000 \\
\hline $\begin{array}{l}\text { Terrestrial Laser } \\
\text { Scanning (TLS) }\end{array}$ & $\begin{array}{l}\text { Point } \\
\text { cloud }\end{array}$ & $<0.01$ & Very high & $\begin{array}{l}\text { c.a. } 200 \times 200 \mathrm{~m} / \\
0.5 \mathrm{~h}\end{array}$ & $\begin{array}{l}2 \mathrm{mln} / \\
30 \mathrm{~min}\end{array}$ & $\begin{array}{c}\text { Yes/ each } \\
\text { plants }\end{array}$ & Yes/no & $\begin{array}{l}100 \times 100 \mathrm{~m} \\
1 \mathrm{~h}\end{array}$ & 2 & 14,000 \\
\hline Mobile DGPS & $\begin{array}{l}\text { Points, } \\
\text { lines }\end{array}$ & $0.1-0.5$ & $\begin{array}{l}\text { Medium- } \\
\text { high }\end{array}$ & $10 \times 500 \mathrm{~m} / 0.5 \mathrm{~h}$ & 400 & $\begin{array}{c}\text { Yes/ each } \\
\text { plants }\end{array}$ & $?$ & $\begin{array}{l}100 \times 100 \mathrm{~m} \\
0.5 \mathrm{~h}\end{array}$ & $2-3$ & $?$ \\
\hline Mobile TLS & $\begin{array}{l}\text { Point } \\
\text { cloud }\end{array}$ & $0.1-1$ & High & $200 \times 500 \mathrm{~m} / 0.5 \mathrm{~h}$ & $\begin{array}{c}6 \mathrm{mln} \text { (one } \\
\text { device) }\end{array}$ & $\begin{array}{l}\text { Yes/ each } \\
\text { plants }\end{array}$ & $?$ & $\begin{array}{l}100 \times 100 \mathrm{~m} \\
0.5 \mathrm{~h}\end{array}$ & $2-3$ & $?$ \\
\hline Smartphone GPS & $\begin{array}{l}\text { Points, } \\
\text { lines }\end{array}$ & Unknown & $\begin{array}{l}\text { Low (will } \\
\text { grow) }\end{array}$ & Unknown & Unknown & Unknown & $?$ & Unknown & 1 & $?$ \\
\hline $\begin{array}{l}\text { Fixed video } \\
\text { cameras and } \\
\text { imagery }\end{array}$ & Image & $\begin{array}{l}\text { Unknown } \\
\qquad(10 \mathrm{~cm}- \\
\text { last } \\
\text { measures })\end{array}$ & $\begin{array}{l}\text { Low to } \\
\text { medium }\end{array}$ & $100 \times 100 \mathrm{~m} /$ at once & Unknown & $\begin{array}{c}\text { Yes/ each } \\
\text { plants }\end{array}$ & No & Unknown & 1 & $?$ \\
\hline
\end{tabular}

${ }^{a}$ Varying because of weather condition, reader skills, surface stability (e.g. loose sand surface) 
A
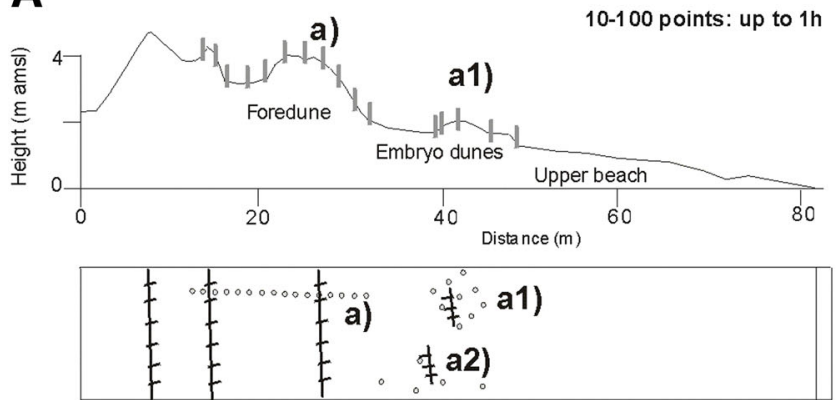

C

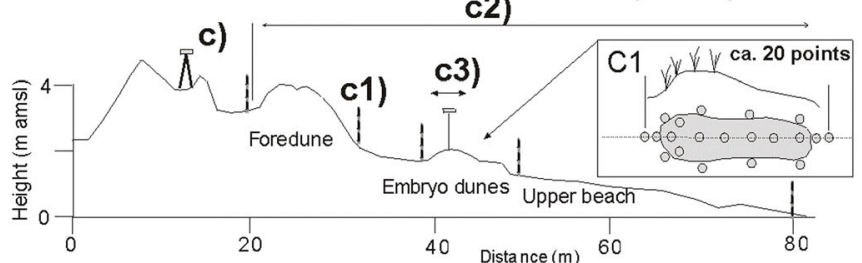

Fig. 10 The technical solution of fieldwork techniques (with marked point reading per amount of time). a simple rod experiment, a) rods in line, every known distance, $a 1$ ) rods in surface plot, $a 2$ ) scattered rods on. b leveling, $b$ ) leveler position no.1, piles marking relief change along transect (line), b2) surface plot with piles/rods. c RTK GPS experiment, c) GPS base fixed position, $c 1$ ) piles marking different relief parts, $c 2$ )

\section{Usefulness comparison of field methods for foredune surveys}

Field measurement is important for observing short-term and long-term relief changes. Long-term measurements give the annual trends in dune dynamics. Superimposed surface transects or surface reliefs allow the specification of the variability of dunes. Their dynamics and volume changes can be analysed using various indicators, such as ridge height, dune foot position, embryo dune growth, or beach width; height change data are the most useful for coastal dune analyses (Labuz 2013). The field measurements methods in coastal dunes are best if we are collecting data about changes occurring on a short time scale or if data are needed immediately.

Each described method provides a different set of data (Table 2). The measurement technique, accuracy, and aim of each measure is also different (Table 3; Fig. 10). The simple measurements using fixed rods or optical leveling are suitable for obtaining point data or linear data. In some conditions, small surface areas can be measured. Some of the methods may be used after dusk, with or without additional light. The obtained data are mostly points or lines. The reading errors of simple methods may be less than $0.5 \mathrm{~cm}$. This depends on the
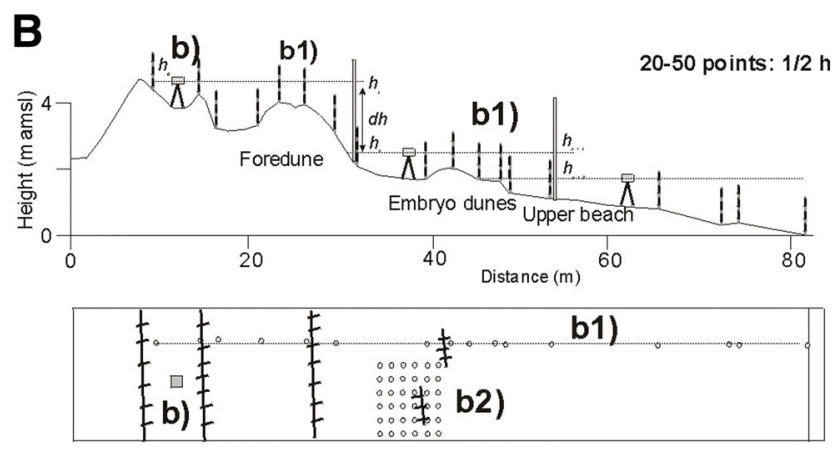

D
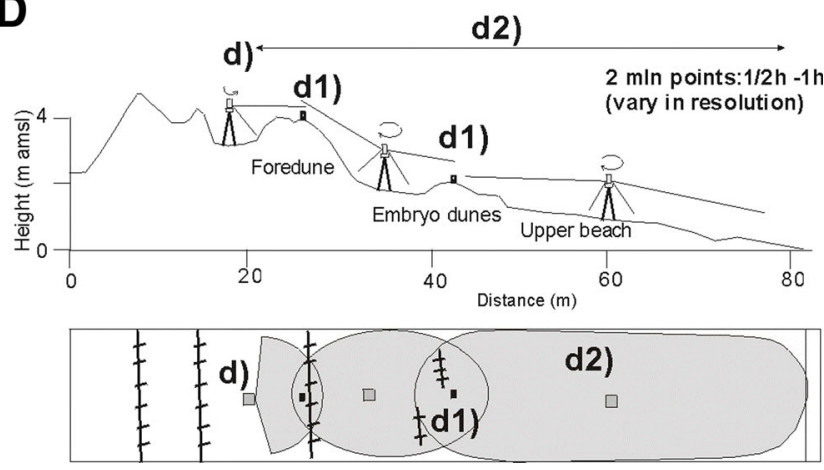

area under RTK measurement, c3) RTK rover moved around marked area. $C l-$ number and position of points needed to mark small embryo dune relief. d TLS experiment, $d$ ) positions of scanner, $d 1$ ) marking points for point cloud fixation from different scanner position, $d 2$ ) scanned area

accuracy and completeness read by the researcher. The leveller measurement error depends on the optical reading, light conditions, and usage of the measure pile. This error is roughly smaller than $1 \mathrm{~cm}$.

Conventional and DGPS methods are often integrated in coastal field work (Harley et al. 2011). The newest digital devices are suitable for obtaining accurate surface data. The GPS RTK is also suitable for point data collection (Andrews et al. 2002). Those devices need to operate in real coordinate systems. The remote areas that are devoid of this possibility need to be investigated by simple methods using local coordinates. Currently, large sets of data are analysed by computer programs and related techniques. Processed data are stored in the GIS database and are used for coastal change prediction (Mitasova et al. 2005). These methods are more costly because of the special software used, which is not inexpensive. The GPSRTK measurement error depends on the accuracy of the employed mobile rover, and it is usually less than $0.5 \mathrm{~cm}$, or even less than $0.4 \mathrm{~cm}$ (Dornbusch 2010). The TLS measurement error depends on the accuracy of the reading device and on its type; it is usually less than $3 \mathrm{~mm}$. The scanner device transmission error may be lower than $0.017 \mathrm{~cm}$ (Feagin et al. 2012; Montreuil et al. 2013b). 
The mobile devices mounted on vehicles can shorten the measurement time of research conducted mainly on the beach (flat surface, easy to drive). The accuracy of data obtained from mobile research is lower than more stationary research. The DGPS RTK field accuracy of foot measurement is better than $0.5 \mathrm{~cm}$ (Harley et al. 2011), and wheel/mobile techniques have an accuracy of $1 \mathrm{~cm}$ (Baptista et al. 2008). The ground laser (TLS) point clouds are collected with a resolution of up to $3 \mathrm{~cm}$, while the mobile laser (MLS) is able to scan quickly a long shoreline with a resolution not less than $10 \mathrm{~cm}$.

The weather conditions may strongly affect the measurement results and the use of equipment. The plant cover on dunes strongly influences laser scanning. The digital measurements on dunes covered by bushes or forest may be impracticable due to the lack of access to the satellite signal. Some measurements may be undertaken without sunlight. This is needed, for example, during ongoing short-duration experiments. Only the DGPS RTK technique's accuracy is not significantly reduced by environmental factors; the only barrier for this method may be a lack of connection to the satellites.

On the basis of the obtained field data, it is possible to estimate the elevation and form volume change. The surface measurements are usable for 3D digital terrain model (DTM) construction of coastal areas. The accuracy of such a model varies due to the digital computation techniques used in special software such as Surfer or ArcView (Andrews et al. 2002; Montreuil et al. 2013b). This subject will be analysed in another article.

\section{Conclusions}

The idea of using field research methods follows from the need to move quickly along the coast in order to register the changes caused over a short period time or by an experienced phenomenon (e.g. storm surge or heavy wind action). The remote research methods such as aerial photogrammetry or scanning are expensive and are conducted mainly once per year. The selection of the proper method and technique of field coastal dune measurement depends on:

- aim of the investigation (accuracy, data, time scale, etc.),

- surface scale of needed field research,

- time scale of change prediction,

- cost of available devices,

- amount of time available for the investigation, and

- availability of field assistants.

The collected data from those techniques vary on the basis of:

- terrain morphology,

- measurement density,
- accuracy of device, and

- interpolation technique.

Data from the realised studies described in this paper are useful for different time scales of dune dynamics, as well as their relief comparison as points, lines, vectors, 2D maps, volumes, or 3D pictures (Fig. 10). The other conclusions describe technical standards to conduct field research in the environment of the dune coast.

Acknowledgements The facts described in paper are based on rich scientific literature and 20 years of research experience carried on Polish coastal dunes. The experience is also gained during abroad visits to other universities and various dune coasts of the world (United Kingdom, Germany, Netherlands, France, Spain, Italy, Estonia, Latvia, Lithuania, United Arab Emirates, South Africa, Namibia, Israel, Tunisia, Egypt, New Zealand, Australia and few others). I could write this paper thanks to all the colleagues with whom I could discuss the issues relating to the dunes measures. The data used in this paper are collected under the project titled Anthropogenic-Natural Dunes Dynamics (ANDDY) financed by Institute of Marine and Coastal Sciences and my own private funding and Foredune Morphodynamics and Biodiversity (FoMoBi), financed by National Centre for Research and Development (NCBiR).

Open Access This article is distributed under the terms of the Creative Commons Attribution 4.0 International License (http:// creativecommons.org/licenses/by/4.0/), which permits unrestricted use, distribution, and reproduction in any medium, provided you give appropriate credit to the original author(s) and the source, provide a link to the Creative Commons license, and indicate if changes were made.

\section{References}

Andrade F, Ferreira MA (2006) A simple method of measuring beach profiles. J Coast Res 22(4):995-999

Andrews B, Gares PA, Colby JD (2002) Techniques for GIS modeling of coastal dunes. Geomorphology 48(1-3):289-308

Anfuso G, Dominguez L, Gracia FJ (2007) Short and medium-term evolution of a coastal sector in Cadiz, SW Spain. Catena 70:229-242

Baptista P, Bastos L, Bernardes C, Vunha T, Dias J (2008) Monitoring sandy shores morphologies by DGPS -a practical tool to generate digital elevation models. J Coast Res 24:1516-1528

Delgado I, Lloyd G (2004) A simple low cost method for one person beach profiling. J Coast Res 20(4):1246-1254

Dornbusch U (2010) Ground survey methods for mixed sand and gravel beaches in intertidal environments: a comparison. J Coast Res 26(3): 451-464

Emery KO (1961) A simple method of measuring beach profiles. Limnol Oceanogr 6:90-93

Feagin RA, Williams AM, Popescu S, Stukey J, Washington-Allen RA (2012) The use of terrestrial laser scanning (TLS) in dune ecosystems: the lessons learned. J Coast Res, 10.2112/JCOASTRES-D-11002231

Harley MD, Turner IL, Short AD, Ranasinghe R (2011) Assessment and integration of conventional, RTK-GPS and image-derived beach survey methods for daily to decadal coastal monitoring. Coast Eng 58(2):194-205

Hesp P (2002) Foredunes and blowouts: initiation, geomorphology and dynamics. Geomorphology 48:245-268

Hesp PA (2013) A 34 year record of foredune morphodynamics at Dark Point, NSW, Australia. In: Conley DC, Masselink G, Russell PE, 
O'Hare TJ (eds) Proceedings 12th International Coastal Symposium (Plymouth, England). J Coast Res SI 65:1295-1300

Holland KT, Holman RA, Lippman TC, Stanley J, Plant N (1997) Practical use of video imagery in nearshore oceanographic field studies. Journal of Oceanic Engineering 22(1):81-92

Jeong-Min L, Jun-Yong P, Jin-Yong Ch (2013) Evaluation of sub-aerial topographic surveying techniques using Total Station and RTK-GPS for applications in macro-tidal sand beach environment. In: Conley DC, Masselink G, Russell PE, O'Hare TJ (eds) Proceedings 12th International Coastal Symposium. J Coast Res SI 65:535-540

Khalil R (2007) Enlargement the sighting distance of Sokkia Digital Level SDL30. In: Quality of measurements. Strategic Integration of Surveying Services. FIG Working Week, Hong Kong SAR, China, 13-17 May 2007: 1-14

Khalil R (2013) The accuracy of GIS tools for transforming assumed Total Station surveys to Real Word coordinates. J Geogr Inf Syst 5:486-491

Kizil U, Tisor L (2011) Evaluation of RTK-GPS and Total Station for applications in land surveying. J Earth Syst Sci 120(2):215-221

Krause G (2004) The "Emery-Method" revisited: performance of an inexpensive method of measuring beach profiles and modifications. J Coast Res 20(1):340-346

Łabuz TA (2003) Initial foredune field as a factor of accumulative character of coastal dunes of the Swina Gate Barrier (West Polish coast). Oceanol Hydrobiol Stud XXXII(1):39-58

Łabuz TA (2009) The increase of the coastal dune area of the Swina Sandbar, West Polish coast. Z Dtsch Ges Geowiss (ZDGG) 160(2):123-135

Łabuz TA (2011) Wpływ spiętrzeń sztormowych na przebudowę profilu wybrzeża wydmowego Mierzei Bramy Świny. Czasopismo Geograficzne 82(4):351-371

Łabuz TA (2013) Polish coastal dunes - affecting factors and morphology. Landf Anal 22:33-59

Labuz TA (2014) Erosion and its rate on an accumulative Polish dune coast: the effects of the January 2012 storm surge. Oceanologia 56(2):307-326

Łabuz TA (2014b) Zastosowanie naziemnego skaningu laserowego w badaniach morfografii klifowych i wydmowych nadbrzeży morskich. In: Rudowski S, Sitkiewicz P, Wróblewski R, (eds) II Sympozjum Morskiej Geomorfologii. Poziom Morza, linia brzegowa. Instytut Morski w Gdańsku, Zakład Oceanografii Operacyjnej, 24.10.2014, Gdańsk, Polska, pp 38-39

Łabuz TA (2015) Coastal dunes: changes of their perception and environmental management. In: Finkl ChW, Makowski Ch (eds) Environmental management and governance. Advances in coastal and marine resources series, Coastal Research Library, Vol. 8, Springer, (441p.), pp 323-410

Łabuz TA, Sławińska J, Osóch P (2012) Issues of coastal dunes mapping in Poland. In: Book of abstracts: IAG/AIG International Workshop on "Objective Geomorphological Representation Models: Breaking through a New Geomorphological Mapping Frontier" University of Salerno, Cilento \& Vallo di Diano Geopark, Salerno, Italy, 1519.10.2012, pp. 85-87

Lee J-M, Park J-Y, Choi J-Y (2013) Evaluation of sub-aerial topographic surveying techniques using Total Station and RTK-GPS for applications in macro-tidal sand beach environment. In: Conley DC, Masselink G, Russell PE, O'Hare TJ (eds) Proceedings 12th International Coastal Symposium. J Coast Res SI 65:535-540

Michoud C, Carrea D, Augereau E, Cancouët R, Costa S, Davidson R, Delacourt CH, Derron M-H, Jaboyedoff M, Letortu P, Maquaire O (2013) Mobile Laser Scanning along Dieppe coastal cliffs: reliability of the acquired point clouds applied to rockfall assessment. EGU General Assembly 2013, 7-12 April, Vienna, Austria

Mitasova H, Overton M, Harmon RS (2005) Geospatial analysis of a coastal sand dune field evolution: Jockey's Ridge, North Carolina. Geomorphology 72:204-221

Montreuil A-L, Bullard JE, Chandler JH (2013a) Detecting seasonal variations in embryo dune morphology using a terrestrial laser scanner In: Conley DC, Masselink G, Russell PE, O'Hare TJ (eds) Proceedings 12th International Coastal Symposium. J Coast Res SI 65:1313-1318

Montreuil A-L, Bullard JE, Chandler JH, Millett J (2013b) Decadal and seasonal development of embryo dunes an accreting macrotidal beach: North Lincolnshire, UK. Earth Surf Process Landf 38(15): 1851-1868

Pardo-Pascual JE, Garcia-Asenjo L, Palomar-Vazquez J, GarriguesTalens P (2005) New methods and tools to analyze the beach-dune system evolution using Real Time Kinematic Global Positioning System and Geographic Information Systems. J Coast Res SI 49: 34-39

Pilecki R (2012) Zastosowania naziemnego skanera laserowego. Czasopismo Techniczne zeszyt 26, rok 109:223-233

Radcliffe D (1999) Feature: how digital levels work. Prof Surveyor 19(5): $10-21$

Silva A, Taborda R, Catalão J, Freire P (2009) DTM extraction using video-monitoring techniques: application to fetch limited beach. J Coast Res SI 56:203-207

Uunk L, Wijnber KM, Morelissen RM (2010) Automated mapping of the intertidal beach bathymetry from video images. Coast Eng 57:461469 